This is a manuscript version of:

Lajos Rózsa, and Zoltán Vas

\title{
Host correlates of diversification in avian lice
}

Published as chapter $11^{\text {th }}$ in:

Morand S, Krasnov B, Littlewood T (eds.) 2015. Parasite diversity and diversification: evolutionary ecology meets phylogenetics. pp 58-76. Cambridge University Press.

11.1 A brief natural history of avian lice

11.1.1 Origins, polyphyly and host distribution of parasitic lice

Booklice (Psocoptera) are primitive hemipteroid insects (Bess et al., 2006) that first appeared in the Permian, 295-248 million years ago (mya). They are small (1-4 mm, rarely up to $10 \mathrm{~mm}$ ), either winged or wingless insects feeding on organic debris, algae and fungi. They are often found in the nests of birds and mammals, including human buildings, and regularly found as phoretic partners on the bodies of these animals.

At least one lineage of archaic psocopterans switched to a parasitic way of life in the Early to Mid Cretaceous (115-130 mya), giving rise to the order of parasitic lice (Phthiraptera). A growing body of morphological (Yoshizawa \& Johnson, 2006) and molecular (Johnson et al., 2004; Murrell \& Barker, 2005; Yoshizawa \& Johnson, 2010) evidence unequivocally suggest that switching to parasitism occurred as two separate and independent events. One suborder of lice, Amblycera, appears to be a sister-clade of the free-living liposcelidid booklice, while all 
other suborders (Ischnocera, Anoplura, Rhyncophthirina) form a separate, though closely related, lineage. Early mammals, birds or even feathered theropod dinosaurs might have served as the ancestral hosts of these parasitic lineages. About 15-18 clades of parasitic lice passed through the Cretaceous-Palaeogene boundary (65 mya), when a large-scale mass extinction decimated the majority of animals (Smith et al., 2011).

The global distribution of extant lice is strictly related to the distribution of birds and mammals. Dispersive individuals are rarely found off-host, though amblycerans can run away to abandon a dying individual and some ischnocerans can disperse phoretically utilizing hippoboscid flies (Clayton \& Harbison, 2011). Though they can survive short periods, lice cannot feed, grow, develop or multiply off-host.

The majority of extant lice parasitize birds; they are less widespread and less species rich on mammals. All but 16 of 173 bird families are known to be parasitized and the number of species known from birds exceeds 3000 (Smith et al., 2011). Many species apparently still await description; however, it seems that the global fauna is relatively well explored at higher taxonomic levels: the last family was described in 1910, and new genera are rarely discovered in recent times (but see Valim \& Weckstein, 2012).

Three amblyceran families occur on birds. Laemobothriids are a large-bodied, species-poor group restricted mostly to accipitriform, ciconiiform, gruiform and falconiform birds. Ricinids are relatively large-bodied parasites of hummingbirds and small passeriforms. Finally, menoponids are relatively small and widely distributed across most avian families. Philopterids are the only ischnocerans occurring on birds. They are relatively small, widely distributed and often specialized morphologically to utilize certain topographic refugia on the feather surfaces suitable to evade host preening - the major cause of their mortality (Clayton et al., 1999). Probably most of the species unknown to science are menoponids and philopterids of small passerines.

Lice are often mentioned as textbook examples for high host specificity. Indeed, a large proportion of known louse species have only been collected from one (or a few closely related) host species, while few others appear to occur across a wide range of host species, genera and 
even families (Price, 1975). Nevertheless, we also have to take into account that (1) the morphological species concept we currently use may be unsuitable for recognizing true biological species (Mey, 2003) and (2) that strict apparent host specificity may simply reflect improper sampling across potential hosts (Poulin, 1992). With these reservations in mind, it is still safe to propose that lice appear to be more host-specific than many other major groups of arthropod ectoparasites such as fleas or ixodid ticks. Not surprisingly, Fahrenholz (1913) used lice to exemplify his hypothesis on host-parasite cospeciation; Hafner and Nadler (1988) also used lice to verify this idea for the first time, and lice remain the focus of cospeciation studies up to the present (Page, 2003). Results of these studies indicate that speciation of lice is sometimes, though by far not always, synchronized with speciation of their hosts more than expected by chance.

\subsubsection{The bird-louse relationship}

Little is known about the feeding habits of avian lice. Laemobothriids and ricinids probably feed on blood (Clay, 1949), at least partially. Menoponids rely on more diverse nutrition; they feed on dead surface tissues of the skin, feather barbs and barbules, and also chew the shaft of developing pin feathers to obtain blood. Philopterids mostly graze the non-living keratin feather barbs and barbules. All lice depend on endosymbiotic bacteria for digestion or additional nutrition that is transmitted transovarially (Johnson \& Clayton, 2003). Predation on feather mites (e.g. Cicchino \& Valim, 2008) or drinking the host eye fluids (Mey, 1978) may provide additional nutrients. The dominant way of transmission is through body-to-body contact among conspecific hosts. Most infestations are established within pair-bonds (e.g. Brooke, 2010) or through parent-offspring contacts (e.g. Darolova et al., 2001). From the parasites' point of view, transmission to the host offspring may have the benefit of living with a naive immune system; however, it also poses the risk of considerably higher host mortality through the first year than in adult birds. Secondary transmission strategies such as phoresy either have a minor role (other than generating host-switches) or do not exist in many taxa.

Infestations may reduce host fitness through reduced thermoregulation (Booth et al., 1993), blood loss (Dik, 2006), the transmission of louse-borne pathogens (Bartlett, 1993) and reduced 
sexual attractiveness to mates (Moreno-Rueda \& Hoi, 2012). Infested birds may even have a reduced longevity (Brown et al., 1995). Therefore, though infestations are not usually pathological in wild birds, they can still benefit from avoiding lice or reducing their numbers.

Birds exhibit behavioural, physiological and morphological adaptations to reduce louse burdens (Clayton et al., 2010). Plumage maintenance behaviours include preening by the bill and scratching by the foot; louse burdens increase dramatically after experimental impairment of preening (Clayton, 1991). Bathing, dust-bathing, sunning (Moyer \& Wagenbach, 1995) and usage of aromatic herbs (Clayton \& Vernon, 1993) probably also play some role in controlling louse burdens. However, the distribution and efficacy of these behaviours are unclear. The formerly presumed role of anting as an antiparasitic defence has recently been challenged by experimental results (Eisner \& Aneshansley, 2008). Little is known about birds' physiological defence against lice. Though the host immune responses and the secretions ('wax') produced by the avian uropygial gland are often presumed to play a role in controlling lice, we lack experimental evidence. Finally, morphologies of avian bills and claws may partially reflect adaptations to combat lice. Several birds have slightly hooked upper mandibles, and this small, curved upper bill overhang is essential for the efficient preening to control ectoparasites (Clayton et al., 2005). Similarly, some avian taxa possess pectinate claws, potentially increasing efficacy of scratching against lice (Bush et al., 2012).

\subsubsection{Lice: animals as contagious pathogens}

In brief, lice are wingless obligate ectoparasitic insects that have traditionally played a prominent role in studying disease ecology. On the one hand, they are contagious pathogens that complete their entire life-cycle in a close and intimate relationship with the host individual. On the other hand, unlike the majority of contagious pathogens, they are insects visible to the naked eye; thus their occurrence, distribution, numbers, sex-ratios and behaviours can be investigated relying on the classical tools and hypotheses of zoology. This makes lice, in general, and the more diverse avian lice, in particular, useful model organisms in the fields of ecological epidemiology, disease ecology and co-evolutionary studies. 
11.2 Patterns of diversification in avian lice

11.2.1 The comparative approach to identify host correlates of louse richness

During the past decades several aspects of the evolutionary ecology of avian lice have been elucidated by experiments. An experimental method is usually superior to correlational including phylogenetically comparative - studies in the sense that the direction of causality between causes and consequences is clarified. On the other hand, experiments are usually restricted to a single or a very few species, and also very limited in time. Accordingly, most evolutionary ecological studies on avian lice are focused on the common ischnocerans of feral pigeons (Columbicola columbae and Campanulotes bidentatus), and do not cover a time span longer than a few months. In contrast, comparative methods enable us to explore macroevolutionary patterns of parasite diversification while, unfortunately, often leaving the question of the direction of causality unanswered.

The first meaningful comparisons of the richness of different louse assemblages predated the emergence of suitable methods to test them statistically. Early authors generalized their observations and proposed that factors like host taxonomical diversity, sociality and body size were likely to affect the taxonomic richness of louse burdens (e.g. Eichler, 1942; Dubinin, 1947; Rothschild \& Clay, 1952). Decades later, Felsenstein's (1985) revelation that comparative analyses should be based on a number of independent comparisons between sister-clades opened the possibility to test such hypotheses in a statistically rigorous way.

Applying phylogenetically controlled methods to test reasonable hypotheses may not always yield reliable results, however. One particular problem is the sensitivity of parasite richness measures to sampling bias. Most of the parasite species living on poorly sampled hosts are probably left unnoticed (Walther et al., 1995) and, paradoxically, even an equal sampling across host species may cause sampling bias. Being all else equal, a host harbouring more aggregated parasite infections has to be sampled more intensively than another host with less aggregated infections in order to explore their parasite faunae to the same level (Rékási et al., 1997). 
When infestation data is detailed for each host individual, several advanced subsampling methods are available to control for the influence of sampling bias on parasite richness. Their reliability has been tested and compared under controlled conditions (Walther \& Morand, 1998). Unfortunately, however, there are usually no means to test their performance in real situations, under real sample size constraints. In contrast, most authors utilize faunistical checklists as a source of rough data that contain only presence/absence data the species level and, therefore, rely on much simpler methods (see below) to control for sampling bias.

A potential further source of weakness roots in the shortcomings of diversity measures applied. The actual values of species richness (most commonly used measure) depend on the arbitrary species concept (Mey, 2003) we adopt. Moreover, since a widely distributed bird species often hosts congeneric louse species, each restricted to different and non-overlapping areas of the host distribution (Clay, 1964), total parasite species richness (as compiled from the literature) overestimates the actual parasite richness that each bird population has to adapt locally (Møller \& Rózsa, 2005).

Some authors get around this problem by using genera richness instead of species richness. Of course, the genus concept is also arbitrary; however, it is free at least from the bias caused by vicariant parasites. Coexisting louse species tend to exhibit distinct body shape and size differences according to the specific microhabitats they occupy in the plumage (Johnson \& Clayton, 2003), such as narrow-bodied 'wing lice' or ovalshaped 'body lice'. Therefore, louse genera can roughly be interpreted as ecological guilds (Simberloff \& Dayan, 1991) utilizing different environmental refuges to avoid host defences. Sampling bias arguably affects genera richness to a smaller extent than species richness because the parasite faunae are more precisely explored on the level of genera than species. Other authors prefer to use the taxonomic distinctness index (Warwick \& Clarke, 1995; Poulin \& Mouillot, 2003) that takes into account both the number of parasite species and their phylogenetic or taxonomical distinctness to quantify diversity. This index is less dependent on sampling effort (Clarke \& Warwick, 1998); however, when applying poor-quality phylogenetic information - e.g. using a taxonomical hierarchy as an estimation of the true phylogeny - it may unwillingly introduce some random noise into the model. 
11.2.2 General surveys for correlates of louse richness

Clayton and Walther (2001) were the first to test host ecological and morphological characters' potential influence on the diversity of avian lice burdens. Their study is based on a single, large sample of Neotropical birds. In spite of applying phylogenetic control and a correction for sampling bias, none of the several host characters examined (geographic range size, local population density, microhabitat, body mass, plumage depth, standard dimensions of bill, foot and toenail) has been found to affect the richness of lice. As a measure of parasite richness, they applied cumulative species richness (first-order jackknife and Chao2 estimations) to control for unequal sampling effort. Apparently, their samples might have contained too few individuals per host species and thus the prerequisites for using these estimation methods were satisfied only by relatively few host species.

Subsequent studies (see below) did not rely on single samples but rather gathered information from global fauna lists, i.e. data collected by several authors through centuries (summarized by Price et al., 2003) but not detailed for host individuals. Hughes and Page (2007) examined ecological correlates of the richness of louse communities harboured by charadriiform, pelecaniform and procellariiform seabirds. This species-rich (440 parasite and 413 host species) louse fauna is probably one of the most accurately explored ones on Earth and thus sampling bias is presumably weak. The authors still found a highly significant relationship between the number of Google Scholar citations for the host species - as a proxy for sampling intensity and both the species and genera richness of lice, making it necessary to control for this interaction statistically by using residuals. They evaluated the relative importance of host morphological (body size, body weight, wingspan, bill length), life-history (longevity, clutch size), ecological (population size, geographical range) and behavioural (diving versus non-diving) variables as predictors of louse species and genera richness across the host species. When applying a statistical control for host phylogeny in single predictor variable tests, host population size and geographic range exhibited positive relationships with residual species richness and genera richness both in amblycerans and ischnocerans. Contrary to expectations, host body mass co-varied negatively with the species richness in both suborders of lice. Additionally, host diving behaviour also had a significant negative effect on louse genera richness (but not species richness), supporting earlier results of Felső and Rózsa (2006). 


\subsubsection{Measures of host defences}

Cotgreave and Clayton (1994) obtained information about the daily time budget of 62 bird species from the literature. These species devote an average of $9.2 \%$ of the daily (daytime) time budget to plumage maintenance behaviours that mostly (93\%) include preening by the bill and scratching by the feet. These behaviours, while also having many other functions in plumage maintenance, partially serve as a defensive behaviour to eliminate lice. To control for potential influence of sampling bias on louse richness, the authors made a linear regression between the study intensity focused on each bird species (log-transformed number of papers published with the host scientific name) and the number of their known louse species, then used the residuals taken from this model as a measure of louse species richness. Pair-wise comparisons along the avian phylogeny supported the view that host species with richer parasite burdens tend to allocate more time to grooming than their sister clades. To interpret this co-variation, the authors considered a one-way direction of causality. They argued that richer louse burdens exert a pressure on birds to devote more time to plumage maintenance.

Møller and Rózsa (2005) explored the potential interaction between host immunological defences and louse genera richness. In a phylogenetically controlled comparison across 80 European altricial bird species, amblyceran genera richness (controlled for sampling bias in a similar manner to above) was predicted by the intensity of T-cell mediated immune response of nestling hosts, while the T-cell immune response of adults had no significant effect. In contrast, ischnoceran genera richness did not correlate with any measures of T-cell responses. Apparently, the richness of amblycerans (which have more bodily contacts with the living host tissues) coevolve with host immune capabilities, while ischnocerans (having less direct contacts) do not engage in similar relationships. To interpret their results, the authors considered the possibilities of two opposite directions of causality. First, they did not exclude that more diverse parasite assemblages may select hosts to allocate more resources into immune defence. Second, they argued that an opposite causality seems to be more plausible; i.e. increasing host allocation to immune defence may increase the diversity of coexisting amblycerans. 
Furthermore, Møller et al. (2010) analysed the evolutionary co-variation of the avian uropygial gland size (controlled for body mass) and genera richness of louse assemblages (controlled for sampling bias). Since this gland produces secretions that are applied to the plumage and are presumed to have antiparasitic effects, the authors used relative gland size as a proxy of antiparasitic defence. A phylogenetically controlled comparison across 212 bird species resulted in a significant positive relationship between relative gland size and amblyceran genera richness. In contrast, ischnoceran richness exhibited no coevolutionary relationship with this aspect of host defences. Again, the authors proposed that the scenario that amblyceran lice diversify in response to intensive host physiological defences was more likely than the opposite causality.

11.2.4 Avian cognitive capabilities coevolve with amblyceran richness

Just like the vertebrate brain, the immune system is also highly expensive in terms of energy and nutrients. Therefore, it seems logical to hypothesize that species that allocate more energy and nutrients to achieve higher cognitive capabilities must reduce resources allocated to antiparasitic defences. Do the reduced defences of 'clever' families yield taxonomically poorer louse burdens? Vas et al. (2011) applied formerly published data sets for brain size and for feeding innovation rates as a proxy for cognitive capabilities (behavioural flexibility) to characterize each avian family. Using data for 108 avian families (and controlling for host species diversity, phylogeny, body size and research effort), they found a highly significant positive relationship between host cognitive capabilities and the taxonomic richness of amblycerans in parallel with the lack of similar relationships in ischnocerans. Host brain size had a similar but much weaker effect. Thus, the results contradict the expectations based on the combination of (1) presumed trade-off between host cognitive capabilities and antiparasitic defences, and (2) the presumed positive relationship between host defences and parasite diversity.

The authors proposed alternative and mutually non-exclusive hypotheses to explain this phenomenon. More innovative birds may exploit a wider diversity of habitats and thus contact more other avian taxa, enabling non-specific lice to switch more frequently to them. 
Furthermore, large-brained birds may be more social, having higher prevalence of lice that lowers the risk of louse extinction at host population size bottlenecks. Alternatively, the relationship between the defensive capabilities and parasite richness across host taxa may not be positive - as shown by Møller and Rózsa (2005) and Møller et al. (2010) - but negative, as proposed by Bordes et al. $(2008 ; 2011)$.

11.3 Eichler's rule: positive co-variation between the taxonomic richness of hosts and parasites

It seems sensible to presume that more diverse host communities can maintain more diverse parasite communities - a potential relationship testable across different levels from small habitat patches (Hechinger \& Lafferty, 2005) up to the global biosphere (Lafferty, 2012). An early formulation of this relationship was given by Eichler (1942), who postulated a positive covariation between the taxonomic richness of hosts and that of their parasites, later dubbed as 'Eichler's rule'. Accordingly, the potential effect of the host clades' taxonomic richness has been controlled for as a potentially confounding variable in some of the earlier studies (e.g. Vas et al., 2011) or at least the authors claimed that host richness did not differ between the sister-clades they compared (e.g. Felső \& Rózsa, 2006; 2007).

Vas et al.'s (2012) study covered the global louse fauna to test this co-variation. In a phylogenetically controlled and sampling bias-corrected comparison they found an extremely strong correlation between the species richness of avian and mammalian families and generic richness of their lice (Figure 11.1). When tested separately for the major taxa of lice, all families parasitizing birds (but the species-poor laemobothriids) and all three suborders parasitizing mammals provided highly significant co-variations independently of each other. Assuming the same situation holds for other parasites, it seems safe to propose that Eichler's rule describes one of the most influential factors generating global biodiversity as whole. 


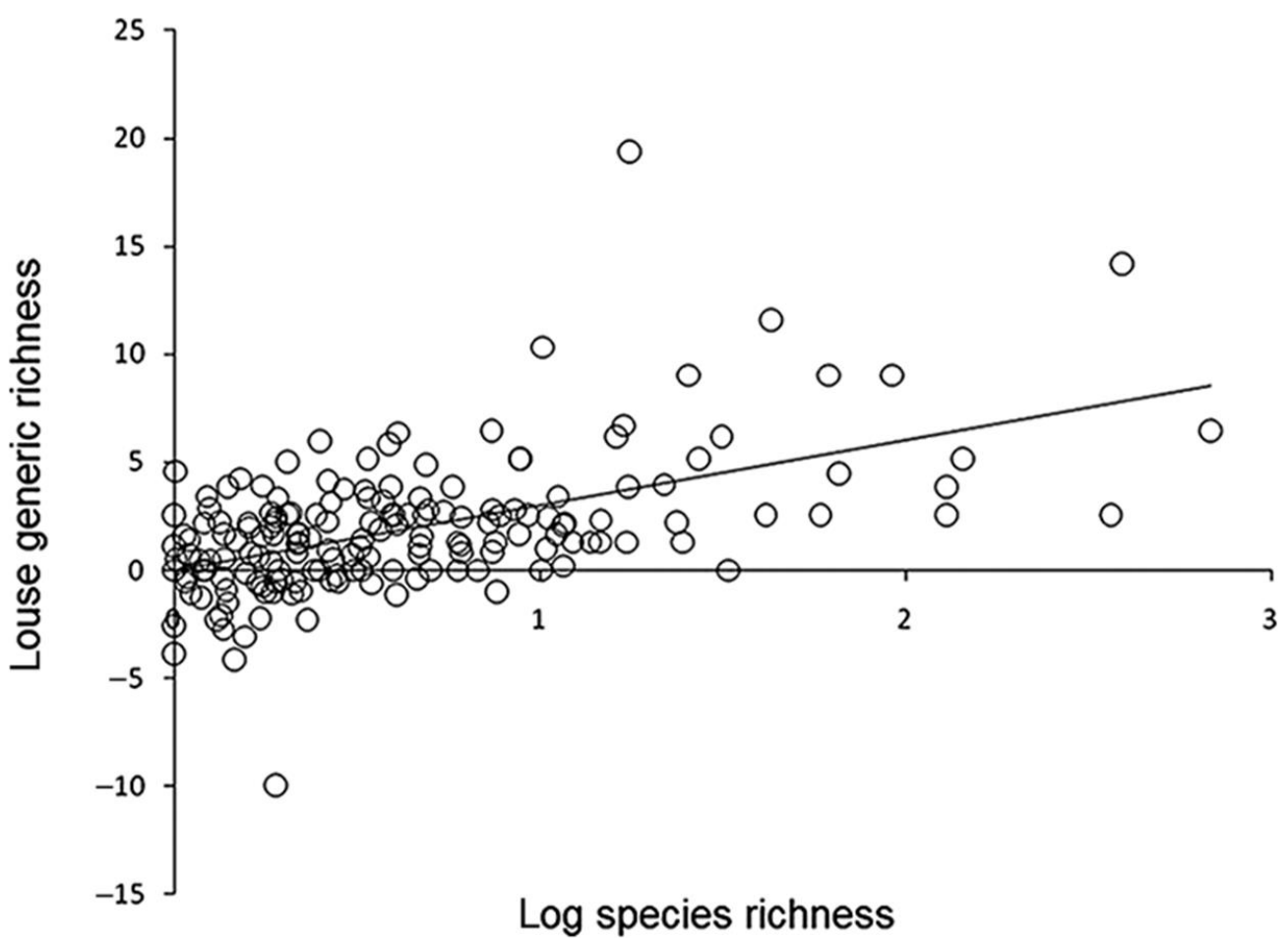

Figure 11.1 As predicted 70 years earlier by Eichler (1942), host clades' taxonomic richness appears to be an influential factor affecting diversification in avian lice. A phylogenetically controlled comparative analysis across avian families revealed a highly significant positive relationship between contrasts of host species richness and the genera richness of the louse fauna they harbour (data from Vas et al., 2012).

11.4 Factors decreasing the richness of louse assemblages

Based on anecdotal evidence, past bottlenecks in host population size have long been presumed to cause a long-lasting loss of louse species (Rózsa, 1993). More recent studies succeeded in verifying this hypothesis by means of comparative data. Taking the birds introduced into New Zealand as an example, Paterson et al. (1999) showed that most of them harbour reduced louse burdens as compared to their source populations (but see MacLeod et al., 2010).

Felső and Rózsa (2006; 2007) compared the genera richness of louse harboured by aquatic versus terrestrial sister-clades along the avian and mammalian phylogeny. They classified those hosts as 'aquatic' that dive beneath the water surface to obtain food and concluded that these 
clades tend to harbour significantly reduced louse faunae. A similar phenomenon is also known in, for example, parasite fauna of pinnipeds; seals seem to host a reduced subset of the parasites characteristic to terrestrial carnivores (Aznar et al., 2001). Within their unsaturated parasite communities, seals also harbour lice that are active only during the hosts' short terrestrial phase of life (Leonardi et al., 2012).

\subsection{Cuckoo lice and host metapopulation structures}

Brood parasitic birds, their foster species and their ectoparasites make a three-level coevolving system. Effects of host birds' brood parasitic lifestyle on the diversification of their lice have been recently analysed by Vas et al. (2013) in a series of phylogenetically controlled and sampling bias-corrected tests. They have shown that host clades' past switches to brood parasitism (seven independent events) had reduced the genera richness and taxonomic distinctness index of both amblycerans and (to a lesser extent) ischnocerans. Also, focusing on the louse burdens of brood parasitic cuckoos (Cuculiformes), they found a positive evolutionary co-variation between the richness measures (species richness, genera richness and taxonomic distinctness) of cuckoos' ischnoceran lice and the number of their foster species. The authors proposed that this relationship is possibly due to the complex and dynamic subpopulation structure of more foster-generalist cuckoo species. Cuckoo body mass also co-varied positively with each measure of ischnoceran richness.

\subsection{Conclusions}

Summarizing the above results (Table 11.1), the picture of relationships between avian characters and the diversification of their parasitic lice is a bit equivocal. Studies that covered several potential host characters either failed to find any relationships (Clayton \& Walther, 2001) or at least found fewer than hoped for (Hughes \& Page, 2007). In contrast, several studies have yielded apparently significant results by focusing on one or just a few host characters. Nevertheless, it is often doubtful in this latter case whether hidden co-variations between the host character actually examined and other characters not involved in the particular study may 
cause false significant results. Thus, controlling at least for the most influential factors among those already outlined by former studies is a major prerequisite for future studies.

Another point to consider is that amblycerans (represented on birds mostly by Menoponidae) and ischnocerans (Philopteridae) are not only distinct by their phylogenetic origin, but also exhibit dissimilar relationships to their hosts. Unlike ischnoceran diversity, amblyceran diversity coevolves with host physiological defence capabilities like T-cell immune response, uropygial gland size and even host cognitive capabilities (in presumed trade-off with physiological defences).

Furthermore, though the different measures of louse diversity (such as species richness, genera richness, taxonomic distinctness)may not be statistically independent of each other, they still capture biologically different aspects of diversity and thus results based on different measures or not fully comparable. Taking Vas et al.'s (2013) cuckoo lice study as an example, some richness measures react negatively to the host clades' switch to brood parasitism, and other measures react positively to the diversity of their foster parents.

An important question to be addressed in the future is the direction of causality beyond the positive relationship between parasite taxonomic richness and host defensive capabilities. Cotgreave and Clayton (1994) gave only a one-direction explanation of this relationship, i.e. diverse parasite assemblages exert a selective pressure upon the host to allocate more time and energy to defence. Subsequently, Møller and Rózsa (2005) and Møller et al. (2010) suggested that an opposite direction of causality may be more plausible; i.e. host species that allocate more resources into antiparasitic defences exert greater selective pressure upon parasites to diversify more intensively or - at least - enable the coexistence of more parasite species within the same community. This latter argument that more intensive host defences make parasite assemblages more diverse is based solely on a presumed parallelism. The authors proposed that in freeliving animal communities, the removal of top predators decreases the diversity of coexisting prey species, and a similar effect may be responsible for the relationship between host defence intensity and parasite richness. Understanding the direction of causality - e.g. by an experimental approach - and its generality would potentially have far- 
reaching consequences. Apparently, humans and domestic animals host far more diverse parasite communities than any other species on Earth. Is it because we allocate more resources into antiparasitic defences (including pharmaceuticals) to save ourselves and domestic animals than any other species on Earth? This hypothesis, if verified, would yield a paradoxical prediction for the future of humankind: the more pharmaceutical efforts we allocate into the personal antiparasite defences of individuals, the more diverse the parasite assemblage that utilizes us as a species. Thus, present medication may increase the future need for medication. This is particularly important because more diverse pathogen assemblages exhibit greater virulence (e.g. Nowak \& May, 1994) and exert stronger selective pressures (Bordes \& Morand, 2009) upon hosts. According to a recent hypothesis (Rózsa, 2008) our pre-human and human ancestors were subjected to greater selective pressures by pathogens and parasites than any other species of apes because they were larger-bodied, more sedentary, more predatory and scavenging in their feeding habits, obtained more food (bivalves and fish) from the water and had more sex (except for bonobos, of course) than non-human apes. Therefore, as this speculation goes, our ancestors were particularly subjected to pathogenmediated sexual selection for honest signals of good resistance alleles (sensu Hamilton \& Zuk, 1982) - i.e. intelligence. Taking the liberty to play freely with these speculations, one can hypothesize that present-day medications select human pathogens to diversify, thus increasing the selective pressure exerted upon our species so as to increase sexual selection for improved cognition.

Even the starting point of the above argument is unsure, however. We cannot really know whether or not humans harbour more pathogens than other comparable host species because our species has been subjected to far more intensive research efforts than any other species. To a lesser degree, the same is also true for domestic animals. There are several methods to control for the distorting effects of sampling bias, of course. However, the methods designed to reduce sampling bias also introduce a new source of further uncontrolled bias. Unnoticed errors may greatly inflate the bias unintentionally introduced by the bias-control procedures themselves. When controlling for sampling intensity, differences in the Palearctic birds, e.g. an error caused by the European wren, may greatly distort results simply because its scientific name (Troglodytes troglodytes) also occurs in the name of an intensively researched chimp subspecies (Pan troglodytes troglodytes) - an accidental coincidence greatly inflating the apparent number of hits in the literature (Møller et al., 2010). Overall, the main problem is that the efficacy of the different methods to correct for sampling bias is mostly unexplored. 
Therefore, the validity of pathogen diversity comparisons across great study intensity differences - such as comparisons between humans and nonhuman animals, or between domesticated animals and wildlife - are highly questionable.

Table 11.1 Summary of phylogenetically controlled and sampling bias-corrected studies on the relationships between diversity measures of avian lice and host correlates.

\begin{tabular}{|c|c|c|c|c|c|c|c|c|c|c|}
\hline \multirow[t]{2}{*}{ Host character } & \multicolumn{3}{|c|}{$\begin{array}{l}\text { Phthiraptera } \\
\text { (when not separated } \\
\text { to suborders) }\end{array}$} & \multicolumn{3}{|c|}{ Amblycera } & \multicolumn{3}{|c|}{ Ishnocera } & \multirow[t]{2}{*}{ Source } \\
\hline & SR & GR & GTI & SR & GR & GTI & SR & GR & GTI & \\
\hline $\begin{array}{l}\text { Time spent } \\
\text { grooming }\end{array}$ & + & & & & & & & & & Cotgreave \& Clayton, 1994 \\
\hline $\begin{array}{l}\text { Nestling T-cell } \\
\text { immune } \\
\text { response }\end{array}$ & & & & & + & & & & & Møller \& Rózsa, 2005 \\
\hline Diving behaviour & & - & & & & & & & & Felső \& Rózsa, 2006 \\
\hline Diving behaviour & & - & & & & & & & & Hughes \& Page, 2007 \\
\hline Population size & & & & + & & & + & & & Hughes \& Page, 2007 \\
\hline $\begin{array}{l}\text { Geographic } \\
\text { range }\end{array}$ & & & & + & & & + & & & Hughes \& Page, 2007 \\
\hline Body mass & & & & - & & & - & & & Hughes \& Page, 2007 \\
\hline $\begin{array}{l}\text { Uropygial gland } \\
\text { size }\end{array}$ & & & & & & & & + & & Møller et al., 2010 \\
\hline $\begin{array}{l}\text { Cognitive } \\
\text { capabilities }\end{array}$ & & & & & & & & + & & Vas et al., 2011 \\
\hline $\begin{array}{l}\text { Relative brain } \\
\text { size }\end{array}$ & & & & & & & & + & & Vas et al., 2011 \\
\hline $\begin{array}{l}\text { Host clade } \\
\text { species richness }\end{array}$ & & & & & + & & & + & & Vas et al., $2011 ; 2012$ \\
\hline $\begin{array}{l}\text { Switching to } \\
\text { brood parasitism }\end{array}$ & & & & & - & - & & & - & Vas et al., 2013 \\
\hline $\begin{array}{l}\text { Cuckoo foster } \\
\text { parent diversity }\end{array}$ & & & & & & & + & + & + & Vas et al., 2013 \\
\hline $\begin{array}{l}\text { Cuckoo body } \\
\text { mass }\end{array}$ & & & & & & & + & & & Vas et al., 2013 \\
\hline
\end{tabular}

Only the statistically significant positive or negative relationships are indicated. SR - species richness, GR genera richness, TDI - taxonomic distinctness index. 
In the future, we should improve the quality of the rough data utilized; i.e. improve phylogenies, improve species concepts, switch from pure presence/absence data to more complex measures of parasite presence (based on prevalence, intensity, taxonomic distinctness) and improve controls for confounding factors - sampling bias in particular - to obtain a better understanding of diversification in avian lice.

Acknowledgements

This research was supported by the European Union and the State of Hungary, co-financed by the European Social Fund in the framework of TÁMOP 4.2.4. A/2-11-1-2012-0001 'National Excellence' programme. Zoltán Vas was supported by the National Scientific Research Fund of Hungary (OTKA grant no. 108571).

References

Aznar, F. J., Balbuena, J. A., Fernández, M. \& Raga, J. A. (2001). Living together: the parasites of marine mammals. In Evans, P. G. H. \& Raga, J. A. (eds), Marine Mammals: Biology and Conservation. New York: Kluwer Academic/Plenum Publishers, pp. 385-423.

Bartlett, C. M. (1993). Lice (Amblycera and Ischnocera) as vectors of Eulimdana spp. (Nematoda: Filarioidea) in Charadriiform birds and the necessity of short reproductive periods in adult worms. Journal of Parasitology, 79, 85-91.

Bess, E., Smith, V. S., Lienhard, C. \& Johnson, K. P. (2006). Psocodea: Parasitic Lice (Phthiraptera), Book Lice, and Bark Lice, Version 08 October 2006. Tree of Life Project. http://tolweb.org/Psocodea/8235.

Booth, D. T., Clayton, D.H.\&Block, B. A. (1993). Experimental demonstration of the energetic cost of parasitism in free-ranging hosts. Proceedings of the Royal Society of London B, 253, 125-129.

Bordes, F. \& Morand, S. (2009). Parasite diversity: an overlooked metric of parasite pressures? Oikos, 118, 801-806. 
Bordes, F., Morand, S. \& Ricardo, G. (2008). Bat fly species richness in Neotropical bats: correlations with host ecology and host brain. Oecologia, 158, 109-116.

Bordes, F., Morand, S. \& Krasnov, B. R. (2011). Does investment into 'expensive' tissue compromise anti-parasitic defence? Testes size, brain size and parasite diversity in rodent hosts. Oecologia, 165, 7-16.

Brooke, M. (2010). Vertical transmission of feather lice between adult blackbirds Turdus merula and their nestlings: a lousy perspective. Journal of Parasitology, 96, 1076-1080.

Brown, C. R., Brown, M. B. \& Rannala, B. (1995). Ectoparasites reduce long-term survival of their avian host. Proceedings of the Royal Society of London B, 262, 313-319.

Bush, S. E., Villa, S. M., Boves, T. J., Brewer, D. \& Belthoff, J. R. (2012). Influence of bill and foot morphology on the ectoparasites of barn owls. Journal of Parasitology, 98, 256-261.

Cicchino, A. C. \& Valim, M. P. (2008). Three new species of Formicaphagus Carriker, 1957 (Phthiraptera, Ischnocera, Philopteridae), parasitic on Thamnophilidae and Conopophagidae (Aves, Passeriformes). Zootaxa, 1949, 37-50.

Clarke, K. R. \& Warwick, R. M. (1998). A taxonomic distinctness index and its statistical properties. Journal of Applied Ecology, 35, 523-531.

Clay, T. (1949). Piercing mouth parts in the biting lice (Mallophaga). Nature, 164, 617.

Clay, T. (1964). Geographical distribution of the Mallophaga (Insecta). Bulletin of the British Ornithological Club, 84, 14-16.

Clayton, D. H. (1991). Coevolution of avian grooming and ectoparasite avoidance. In Loy, J. E. \& Zuk, M. (eds), Bird-Parasite Interactions: Ecology, Evolution and Behaviour. Oxford: Oxford University Press, pp. 258-289.

Clayton, D. H. \& Harbison, C. W. (2011). Community interactions govern host-switching with implications for host-parasite coevolutionary history. Proceedings of the National Academy of Sciences of the USA, 108, 9525-9529.

Clayton, D. H. \& Vernon, J. G. (1993). Common grackle anting with lime fruit and its effect on ectoparasites. Auk, 110, 951-952.

Clayton, D. H. \& Walther, B. A. (2001). Influence of host ecology and morphology on the diversity of Neotropical bird lice. Oikos, 94, 455-467. 
Clayton, D. H., Lee, P. L. M., Tompkins, D. M. \& Brodie, E. D. (1999). Reciprocal natural selection on host-parasite phenotypes. American Naturalist, 78, 167-171.

Clayton, D. H., Moyer, B. R., Bush, S. E., et al. (2005). Adaptive significance of avian beak morphology for ectoparasite control. Proceedings of the Royal Society of London B, 272, 811-817.

Clayton, D. H., Koop, J. A. H., Harbison, C. W., Moyer, B. M. \& Bush, S. E. (2010). How birds combat their ectoparasites. The Open Ornithology Journal, 3, 41-71.

Cotgreave, P. \& Clayton, D. H. (1994). Comparative analysis of time spent grooming by birds in relation to parasite load. Behaviour, 131, 171-187.

Darolova, A., Hoi, H., Kristofik, J. \& Hoi, C. (2001). Horizontal and vertical ectoparasite transmission of three species of Mallophaga, and individual variation in European beeeaters (Merops apiaster). Journal of Parasitology, 87, 256-262.

Dik, B. (2006). Erosive stomatitis in a white pelican (Pelecanus onocrotalus) caused by Piagetiella titan (Mallophaga: Menoponidae). Journal of Veterinary Medicine B, 53, 153154.

Dubinin, V. B. (1947). Studies on the adaptation of ectoparasites II: ecological adaptations of feather-mites and Mallophaga. Parazitologicheskij Sbornik, 9, 191-222. (in Russian) Eichler, W. (1942). Die Entfaltungsregel und andere Gesetzmäßigkeiten in den parasitogenetischen Beziehungen der Mallophagen und anderer ständiger Parasiten zu ihren Wirten. Zoologischer Anzeiger, 137, 77-83.

Eisner, T. \& Aneshansley, D. (2008). 'Anting' in blue jays: evidence in support of a foodpreparatory function. Chemoecology, 18, 197-203.

Fahrenholz, H. (1913). Ectoparasitien und abstammungslehre. Zoologischer Anzeiger, 41, $371-$ 374.

Felsenstein, J. (1985). Phylogenies and the comparative method. American Naturalist, 125, $1-$ 15.

Felső, B. \& Rózsa, L. (2006). Reduced taxonomic richness of lice (Insecta: Phthiraptera) in diving birds. Journal of Parasitology, 92, 867-869. 
Felső, B. \& Rózsa, L. (2007). Diving behaviour reduces genera richness of lice (Insecta: Phthiraptera) of mammals. Acta Parasitologica, 52, 82-85.

Hafner, M. S. \& Nadler, S. A. (1988). Phylogenetic trees support the coevolution of parasites and their hosts. Nature, 332, 258-259.

Hamilton, W. D. \& Zuk, M. (1982). Heritable true fitness and bright birds: a role for parasites? Science, 218, 384-387.

Hechinger, R. F. \& Lafferty, K. D. (2005). Host diversity begets parasite diversity: bird final hosts and trematodes in snail intermediate hosts. Proceedings of the Royal Society of London B, 272, 1059-1066.

Hughes, J. \& Page, R. D. M. (2007). Comparative tests of ectoparasite species richness in seabirds. BMC Evolutionary Biology, 7, 227.

Johnson,KP.\&Clayton, D. H. (2003). The biology, ecology, and evolution of chewing lice. In Price, R. D., Hellenthal, R. L., Johnson, K. P.\&Clayton, D. H. (eds), The Chewing Lice:World Checklist and Biological Overview, Champaign, IL: Illinois Natural History Survey, pp. 451-475.

Johnson, K. P., Yoshizawa, K. \& Smith, V. S. (2004). Multiple origins of parasitism in lice. Proceedings of the Royal Society of London B, 271, 1771-1776.

Lafferty, K. (2012). Biodiversity loss decreases parasite diversity: theory and patterns. Philosophical Transactions of the Royal Society of London B, 367, 2814-2827.

Leonardi, M. S., Crespo, E. A., Vales, D. G., et al. (2012). Life begins when the sea lion is ashore: microhabitat use by a louse living on a diving mammal host. Bulletin of Entomological Research, 102, 444-452.

MacLeod, C. J., Paterson, A. M., Tompkins, D. M. \& Duncan, R. P. (2010). Parasites lost: do invaders miss the boat or drown on arrival? Ecology Letters, 13, 516-527.

Mey, E. (1978). Augensekret - Trinken bei Mallophagen. Angewandte Parasitologie, 19, 19-20.

Mey, E. (2003). On the development of animal louse systematics (Insecta, Phthiraptera) up to the present day. Rudolstädter Naturhistorische Schriften, 11, 115-134.

Møller, A. P. \& Rózsa, L. (2005). Parasite biodiversity and host defenses: chewing lice and immune response of their avian hosts. Oecologia, 142, 169-176. 
Møller, A. P., Erritzøe, J. \& Rózsa, L. (2010). Ectoparasites, uropygial glands and hatching success in birds. Oecologia, 163, 303-311.

Moreno-Rueda, G. \& Hoi, H. (2012). Female house sparrows prefer big males with a large white wing bar and fewer feather holes caused by chewing lice. Behavioral Ecology, 23, 271277.

Moyer, B. R. \& Wagenbach, G. E. (1995). Sunning by black noddies (Anous minutus) may kill chewing lice (Quadraceps hopkinsi). Auk, 112, 1073-1077.

Murrell, A. \& Barker, S. C. (2005). Multiple origins of parasitism in lice: phylogenetic analysis of SSU rDNA indicates that the Phthiraptera and Psocoptera are not monophyletic. Parasitology Research, 97, 274-80.

Nowak, M. A. \& May, R. M. (1994). Superinfection and the evolution of parasite virulence. Proceedings of the Royal Society of London B, 255, 81-89.

Page, R. D. M. (ed.) (2003). Tangled Trees: Phylogeny, Cospeciation and Coevolution, Chicago, IL: University of Chicago Press. Paterson, A. M., Palma, R. L. \& Gray, R. D. (1999). How frequently do avian lice miss the boat? Implications for coevolutionary studies. Systematic Biology, 48, 214-223.

Poulin, R. (1992). Determinants of host-specificity in parasites of freshwater fishes. International Journal for Parasitology, 22, 753-758.

Poulin, R. \& Mouillot, D. (2003). Parasite specialization from a phylogenetic perspective: a new index of host specificity. Parasitology, 126, 473-480.

Price, R. D. (1975). The Menacanthus eurysternus complex (Mallophaga: Menoponidae) of the Passeriformes and Piciformes (Aves). Annals of the Entomological Society of America, $68,617-622$.

Price, R. D., Hellenthal, R. A. \& Palma, R. L. (2003). World checklist of chewing lice with host associations and keys to families and genera. In Price, R. D., Hellenthal, R. L., Johnson, K. P. \& Clayton, D. H. (eds), The Chewing Lice: World Checklist and Biological Overview. Champaign, IL: Illinois Natural History Survey, pp. 1-447.

Rékási, J., Rózsa, L. \& Kiss, J. B. (1997). Patterns in the distribution of avian lice (Phthiraptera: Amblycera, Ischnocera). Journal of Avian Biology, 28, 150-156. 
Rothschild, M. \& Clay, T. (1952). Fleas, Flukes and Cuckoos: A Study of Bird Parasites. London: Collins \& Son.

Rózsa, L. (1993). Speciation patterns of ectoparasites and 'straggling' lice. International Journal for Parasitology, 23, 859-864.

Rózsa, L. (2008). The rise of non-adaptive intelligence in humans under pathogen pressure. Medical Hypotheses, 70, 685-690.

Simberloff, D. \& Dayan, T. (1991). The guild concept and the structure of ecological communities. Annual Review of Ecology and Systematics, 22, 115-143.

Smith, V. S., Ford, T., Johnson, K. P., et al. (2011). Multiple lineages of lice pass through the KPg boundary. Biology Letters, 7, 782-785.

Valim, M. P. \& Weckstein, J. D. (2012). A new genus and species of Philopteridae (Phthiraptera: Ischnocera) from the trumpeters (Aves: Gruiformes: Psophiidae). Journal of Parasitology, 98, 728-734.

Vas, Z., Lefebvre, L., Johnson, K. \& Rózsa, L. (2011). Clever birds are lousy: co-variation between avian innovation and the taxonomic richness of their amblyceran lice. International Journal for Parasitology, 41, 1295-1300.

Vas, Z., Csorba, G. \& Rózsa, L. (2012). Evolutionary co-variation of host and parasite diversity: the first test of Eichler's rule using parasitic lice (Insecta: Phthiraptera). Parasitology Research, 111, 393-401.

Vas, Z., Fuisz, T. I., Fehérvári, P., Reiczigel, J. \& Rózsa, L. (2013). Avian brood parasitism and ectoparasite richness: scale-dependent diversity interactions in a three-level hostparasite system. Evolution, 67, 959-968.

Walther, B. A. \& Morand, S. (1998). Comparative performance of species richness estimation methods. Parasitology, 116, 395-405.

Walther, B. A., Cotgreave, P., Price, R. D., Gregory, R. D. \& Clayton, D. H. (1995). Sampling effort and parasite species richness. Parasitology Today, 11, 306-310.

Warwick, R. \& Clarke, K. (1995). New 'biodiversity' measures reveal a decrease in taxonomic distinctness with increasing stress. Marine Ecology Progress Series, 129, 301-305. 
Yoshizawa, K. \& Johnson, K. P. (2006). Morphology of male genitalia in lice and their relatives and phylogenetic implications. Systematic Entomology, 31, 350-361.

Yoshizawa, K. \& Johnson, K. P. (2010). How stable is the 'polyphyly of lice' hypothesis (Insecta:

Psocodea)? A comparison of phylogenetic signal in multiple genes. Molecular Phylogenetics and Evolution, 55, 939-951. 